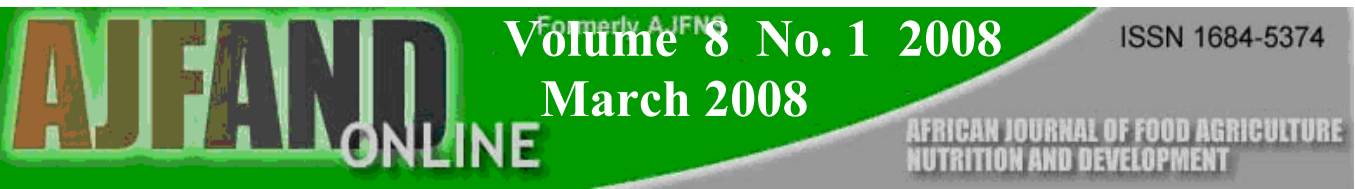

\title{
SECRETION OF METHIONINE BY MICROORGANISMS ASSOCIATED WITH CASSAVA FERMENTATION
}

\author{
Anike $\mathbf{N}^{1}$ and N Okafor ${ }^{2}$
}

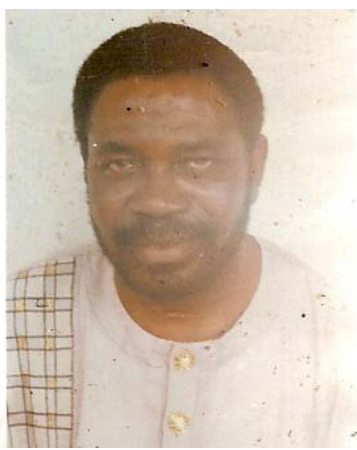

\section{Nduka Okafor}

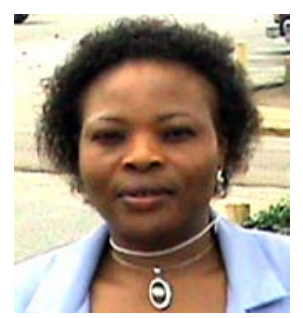

Ngozi Anike

*Corresponding author email: ndukaokafor1@yahoo.com

Department of Applied Microbiology and Brewing, Nnamdi Azikiwe University, Awka, Nigeria

${ }^{1}$ Ngozi Anike - Present address: ARC Building reception, Dept of Food And Animal Science, Alabama A \& M University, P.O.Box 1628 , Normal, Al. 35762; e-mail: ngozianike@yahoo.com

2 *Nduka Okafor - Present address: 132 Long Hall, Department of Biological Sciences, Clemson University, Clemson, South Carolina 29634, USA. Tel: 864646 6060; 8643565203.

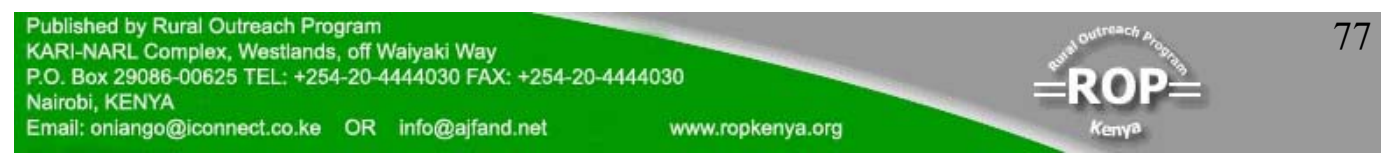




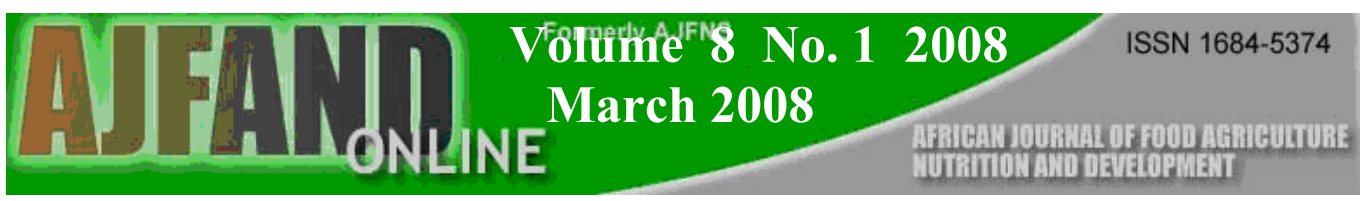

\section{ABSTRACT}

Forty-six (46) bacteria were isolated from different sites associated with garri production from cassava: cassava pulp grated for garri production, grating machines, soil in the vicinity of the production of garri, and utensils involved in the processing of cassava into garri in several locations in Anambra State of Nigeria. Of these, Lactobacillus plantarum, Lactobacillus sp., Leuconostoc sp., Corynebacterium sp. and Bacillus sp. secreted methionine. The organisms were assessed for optimum methionine production at various levels of glucose, ammonium sulphate and varying mixtures of potassium hydrogen phosphate and di-potassium hydrogen phosphate. All the organisms required $10 \mathrm{~g}$ glucose for maximum methionine secretion. All the isolates required $20 \mathrm{~g}$ of $\left(\mathrm{NH}_{4}\right)_{2} \mathrm{SO}_{4} /$ litre, except for Bacillus sp. which required as little as $5 \mathrm{~g}$ of $\left(\mathrm{NH}_{4}\right)_{2} \mathrm{SO}_{4} /$ litre. The organisms' requirement for phosphate varied widely: the two lactobacilli required $0.5 \mathrm{~g} \mathrm{KH}_{2} \mathrm{PO}_{4}$ and $1.5 \mathrm{~g} \mathrm{~K}_{2} \mathrm{HPO}_{4}$ per litre, Leuconostoc sp. and Bacillus sp. required $1.0 \mathrm{~g} \mathrm{KH}_{2} \mathrm{PO}_{4}$ and $3.0 \mathrm{~g} \mathrm{~K}_{2} \mathrm{HPO}_{4}$ per litre. Lactobacillus spp. were the highest secreters of methionine, followed in that order by Leuconostoc sp., Corynebacterium sp. and Bacillus sp. The optimum period of incubation for the secretion varied from $48 \mathrm{~h}$ to $96 \mathrm{~h}$, which is the period for cassava mash fermentation in garri production. The findings on Lactobacillus plantarum, Lactobacillus sp. and Leuconostoc sp. are of importance in any possible effort to increase the methionine content of garri. In this study the maximum quantities of methionine were secreted after 96 hours and 72 hours respectively by the lactobacilli and Leuconostoc sp. Since lactic acid bacteria are micro-aerophilic, it is suggested that lactic acid bacteria (the two lactobacilli and Leuconostoc sp.), which are the major organisms involved in cassava fermentation for garri production, may, in the less aerated environment of the cassava mash, produce more methionine and in shorter time, than observed under the aerobic conditions of this work.

Key words: garri, fermentation, lactic acid, methionine

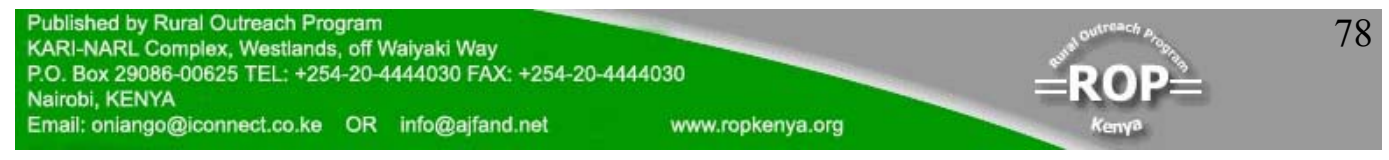




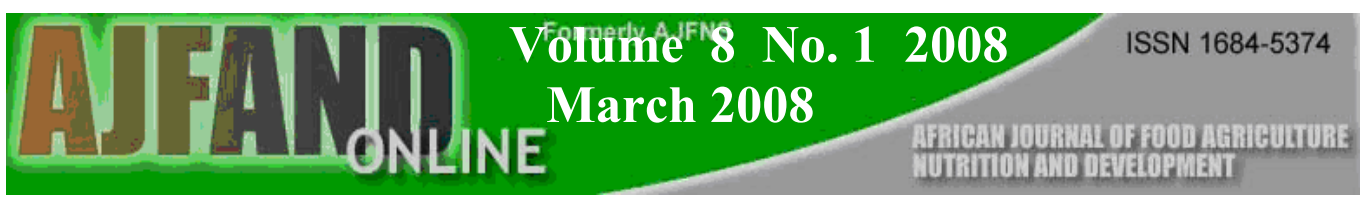

\section{INTRODUCTION}

The enlarged root of the cassava plant, Manihot esculenta Crantz is consumed all over the tropical world, in Africa, Asia and the Caribbean. In West Africa, including Ghana, Cote d'Ivoire, Togo, Cameroon and Nigeria, it is consumed by about 200 million people as garri, which forms a major supply of carbohydrate in these countries. Cassava is poor in proteins and amino acids, including lysine and methionine, and these deficiencies are carried over into foods derived from cassava $[1,2,3]$. The two amino acids have important functions in human health as well as in farm animal nutrition.

Methionine is a principle supplier of sulphur which prevents disorders of the hair, skin and nails; it helps lower cholesterol levels by increasing the liver's production of lecithin; it reduces liver fat and protects the kidneys; it is a natural chelating agent for heavy metals, and finally it regulates the formation of ammonia and creates ammoniafree urine which reduces bladder irritation $[4,5,6]$. When both amino acids are added as supplements into animal feed, a dramatic increase in animal growth rate is observed. Previous studies on the increase in lysine content of garri produced by inoculating cassava mash, from which garri is made, with lysine-secreting microorganisms has been reported $[1,2]$.

This paper reports the first of series of similar studies with methionine and describes the isolation of methionine-secreting bacteria and the optimization of methionine secretion in liquid medium. The production of methionine from various carbohydrates has been discussed [7]. A recent review raised optimism about the production of methionine by fermentation, and suggested ways of overcoming any problems [8]. However, no study has so far linked microbial production of methionine with the possibility of the improvement of a cassava food product.

\section{MATERIALS AND METHODS}

\section{Isolation, identification and storage of bacteria}

One gram of cassava pulp collected from garri processing establishments in Awka, Nimo, Nkwelle, Ogbaru and Nsugbe, all in Anambra State of Nigeria, was shaken in $100 \mathrm{ml}$ of sterile water and streaked on plates of glucose yeast extract agar (GYEA) [9]. Machines used for grating cassava for garri production and utensils for mixing cassava mash were swabbed with sterile swabs and streaked on plates of GYEA. In addition $1 \mathrm{~g}$ of soil was collected at the sites of garri processing in these towns and also shaken in sterile water and plated out on GYEA. The ensuing microorganisms were purified and stored on agar slants of GYEA until they were used. Subsequently,

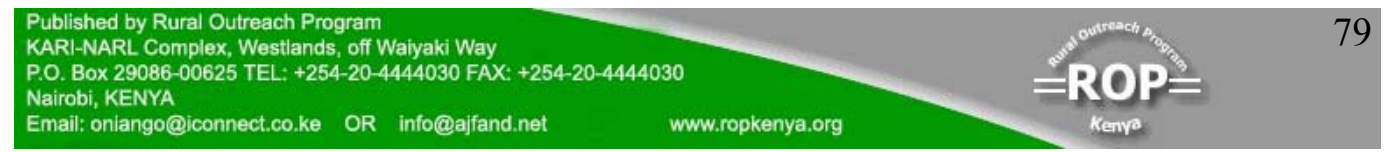




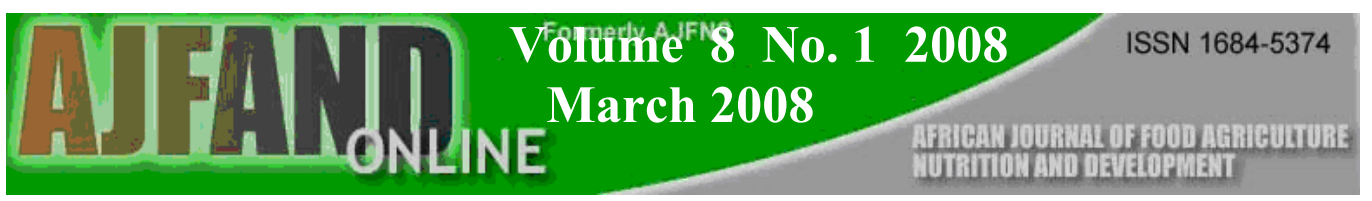

they were identified according to Bergey's Manual of Determinative Bacteriology, $9^{\text {th }}$ Edition [10].

\section{Screening of bacteria for methionine secretion}

The isolates were incubated at room temperature $\left(30^{\circ} \mathrm{C}\right)$ with shaking at $150 \mathrm{rev} / \mathrm{min}$ for $48 \mathrm{~h}$ and thereafter centrifuged at 5,000 x g. [11]. The methionine content of the supernatant was determined by the colorimetric cyanide acetate-ninhydrin method for the analysis of amino acids of Rosen, 1957 using a Spectronic 21 spectrophotometer at $570 \mathrm{~nm}[11,12]$.

\section{Optimization of fermentation conditions for methionine secretion}

Since the nutrient requirements and period of incubation for optimum methionine secretion were likely to be different for each organism, these requirements were studied in two phases. In the first phase, the optimum quantities of carbon, nitrogen and phosphate for methionine production were studied by incubating each organism for 24 and $48 \mathrm{~h}$ in different quantities of glucose, ammonium sulphate and varying mixtures of potassium hydrogen phosphate and di-potassium hydrogen phosphate in a basal medium. The basal medium consisted of $0.5 \mathrm{~g}$ glucose and $5 \mathrm{~g}$ yeast extract (DIFCO) in a litre of distilled water, adjusted to neutral $\mathrm{pH}$.

The second phase was carried out to determine the optimum incubation period for maximum methionine secretion in a medium which contained quantities of carbon, nitrogen and phosphate optimum for methionine secretion for each organism as determined in the first phase experimentation. The organisms were grown in $50 \mathrm{ml}$ of media in $250 \mathrm{ml}$ conical flasks, and shaken $(150 \mathrm{rev} / \mathrm{min})$ at $30^{\circ} \mathrm{C}$ for $24 \mathrm{~h}$ and $48 \mathrm{~h}$ as in the first phase (Tables 1-4) and for six days (144 h) in the second phase (Table 5). Thereafter, methionine in the supernatant was evaluated as described above. All the experiments were replicated thrice and the means reported.

\section{RESULTS}

\section{Isolates}

Of the 46 bacterial isolates, only five were found to be active in methionine secretion. These isolates were subsequently identified as Lactobacillus plantarum, Lactobacillus sp., Corynebacterium sp., Bacillus sp. and Leuconostoc sp., using the $9^{\text {th }}$ edition of Bergey's Manual of Determinative Bacteriology [10].

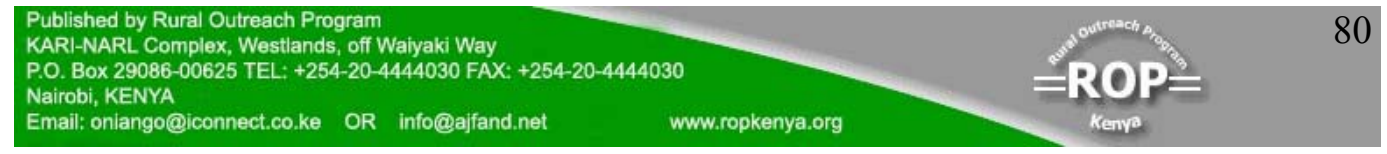




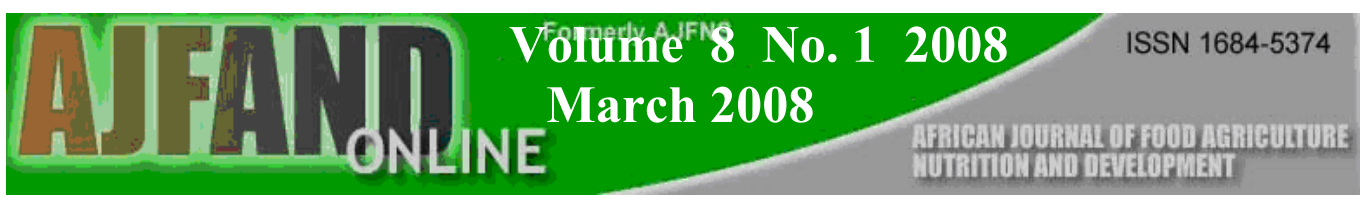

\section{Effect of glucose concentration on methionine secretion}

Table 1 shows that methionine secretion was highest when $10 \mathrm{~g} / 1$ of glucose was used. It was decided not to use more than $10 \mathrm{~g} / 1$ so as to limit the cost of the medium should the findings need to be scaled up for industrial production. Furthermore, the longer the incubation period, the more the methionine secreted. It was decided not to use more than $10 \mathrm{~g}$ of glucose per litre so as not to render the possible scale up of the results of this experiment financially unattractive for industrial adaptation.

\section{Effect of nitrogen and phosphate concentrations on methionine secretion}

Most isolates (Table 2) secreted methionine maximally with $20 \mathrm{~g}\left(\mathrm{NH}_{4}\right)_{2} \mathrm{SO}_{4} /$ litre of medium, except for Bacillus sp. which produced methionine maximally with $5 \mathrm{~g} / \mathrm{l}$.

The effect of phosphate concentrations on methionine secretion is as shown in Table 3 , where it would be seen that the phosphate requirements of the isolates varied widely. The lactobacilli required the least amount of phosphates, Corynebacterium and Bacillus sp. followed and Leuconostoc sp. required the most.

\section{Compounding the Medium Optimum for Methionine Secretion for Each Organism}

Table 4 shows the composition of the medium for each organism's optimal methionine production as determined from the above (phase 1) experiments. All the organisms required $10 \mathrm{~g}$ glucose for maximum methionine secretion. With regard to nitrogen, all the isolates required $20 \mathrm{~g}$ of $\left(\mathrm{NH}_{4}\right)_{2} \mathrm{SO}_{4} /$ litre, except for Bacillus sp. which required as little as $5 \mathrm{~g}$ of $\left(\mathrm{NH}_{4}\right)_{2} \mathrm{SO}_{4} /$ litre. The organisms' requirement for phosphate varied widely: the two lactobacilli required $0.5 \mathrm{~g} \mathrm{KH}_{2} \mathrm{PO}_{4}$ and $1.5 \mathrm{~g}$ $\mathrm{K}_{2} \mathrm{HPO}_{4} /$ litre, Leuconostoc sp. and Bacillus sp. required $1.0 \mathrm{~g} \mathrm{KH}_{2} \mathrm{PO}_{4}$ and $3.0 \mathrm{~g}$ $\mathrm{K}_{2} \mathrm{HPO}_{4} /$ litre.

\section{Optimal Incubation time for the Secretion of Methionine by Each Isolate}

The highest quantities of methionine were produced by the two lactobacilli, after growth for 96 hours: 3.48 and $3.30 \mathrm{~g}$ of methionine per litre, respectively. Corynebacterium sp., Leuconostoc sp. and Bacillus sp. secreted 2.76, (48 h) 2.48 (72 h) and 1.35 (72 h) methionine per litre, respectively.

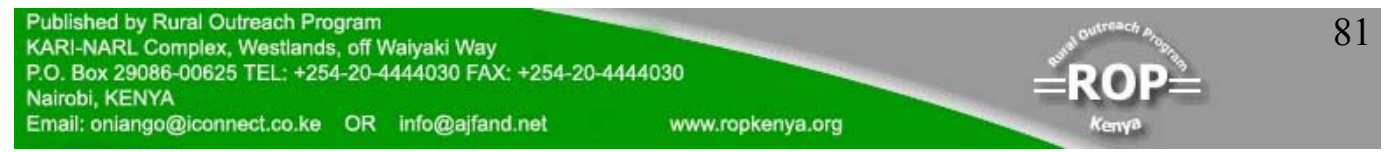




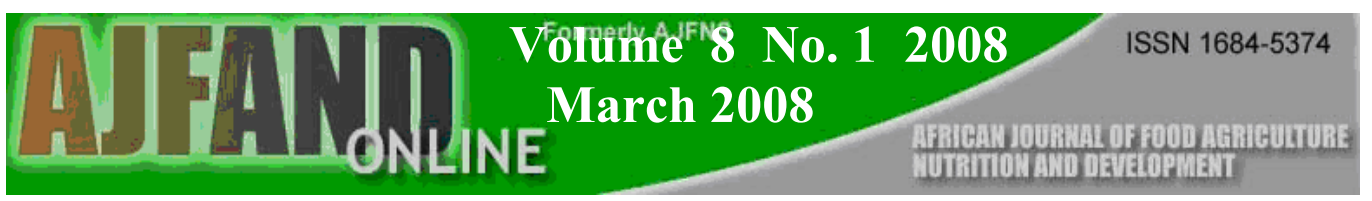

\section{DISCUSSION}

Five of the 46 bacteria isolated from cassava-fermentation related sites and appliances secreted methionine, namely Lactobacillus plantarum, Leuconostoc sp., Corynebacterium sp. and Bacillus sp. For maximum methionine secretion the different organisms required media with different compositions of carbon, nitrogen and phosphate as well as different incubation periods; all organisms were shaken in $50 \mathrm{ml}$ of medium in $250 \mathrm{ml}$ conical flasks at $150 \mathrm{rev}$ per minute at $30{ }^{\circ} \mathrm{C}$. These conditions are summarized in Table 6. The three lactic acid bacteria (Lactobacillus plantarum, Lactobacillus sp. and Leuconostoc sp.) are well known as important agents in cassava fermentation $[1,2,13,14]$. Although Corynebacterium sp. has been described in cassava fermentation, it is not thought to be important and its preponderance in the work of Collard and Levi, was probably due to the use of nutrient agar by the authors rather than media which contain sugar and would encourage lactic acid bacteria to grow $[15,16]$. Published works on cassava fermentation for garri production have not included Bacillus sp. as important agents. The findings on Lactobacillus plantarum, Lactobacillus sp. and Leuconostoc sp. are of importance in any possible effort to increase the methionine content of garri. In this study the maximum quantities of methionine were secreted after 96 hours and 72 hours respectively by the lactobacilli and Leuconostoc $\mathrm{sp}$. In practice, cassava mash is fermented for between 18 and 96 hours, the shorter fermentation period being used in the eastern part of Nigeria, and the longer period in the western. These results are a guide to what might be expected with the organisms to be inoculated into cassava mash. Lactic acid bacteria are known to generally prefer micro-aerophilic conditions where only limited quantities of oxygen are available as is most likely to be the case in the environment of cassava mash. In contrast, the bacteria were grown under aerobic conditions; it is therefore likely that in cassava mash, where the oxygen availability will be limited, more methionine may be secreted within a shorter time.

\section{CONCLUSION}

Methionine secreting bacteria are present in environments associated with garri production from cassava. This amino acid is lacking in cassava and garri produced from it. The work showed that sources exist for the isolation of methionine producers in future studies, aimed at improving garri by inoculating methionine producers into cassava mash fermenting for garri production.

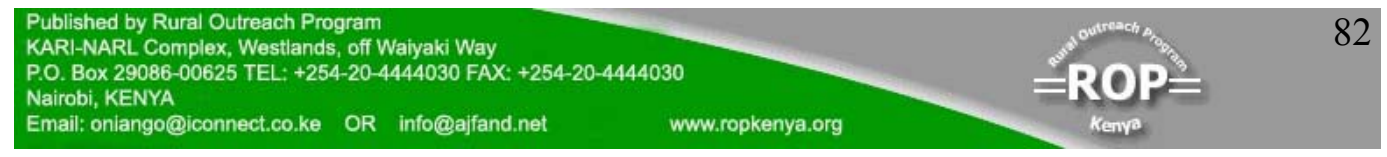




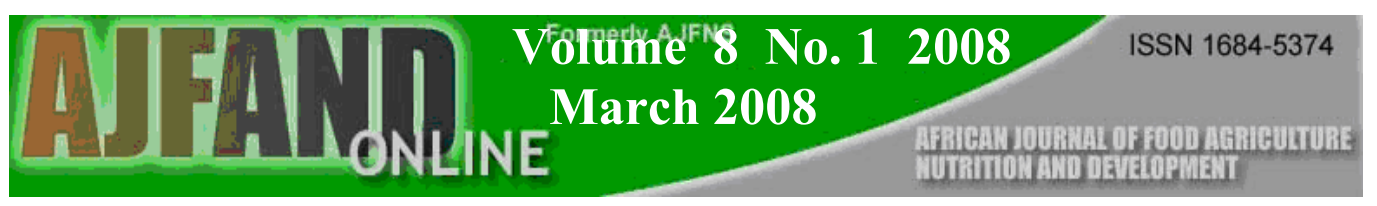

Table 1: Effect of sugar concentration on methionine secretion

\begin{tabular}{|c|c|c|c|c|c|c|c|c|c|c|}
\hline \multirow{3}{*}{ Organisms } & \multicolumn{10}{|c|}{ Methionine Secreted (g methionine/litre of medium) } \\
\hline & \multicolumn{2}{|c|}{$2 \mathrm{~g}$ glucose/litre } & \multicolumn{2}{|c|}{$4 \mathrm{~g}$ glucose/litre } & \multicolumn{2}{|c|}{6 g glucose/litre } & \multicolumn{2}{|c|}{8 g glucose/litre } & \multicolumn{2}{|c|}{$10 \mathrm{~g}$ glucose/litre } \\
\hline & $24 \mathrm{~h}$ & $48 \mathrm{~h}$ & $24 \mathrm{~h}$ & $48 \mathrm{~h}$ & $24 \mathrm{~h}$ & $48 \mathrm{~h}$ & $24 \mathrm{~h}$ & $48 \mathrm{~h}$ & $24 \mathrm{~h}$ & $48 \mathrm{~h}$ \\
\hline $\begin{array}{l}\text { Lactobacillus } \\
\text { plantarum }\end{array}$ & 0.10 & 0.25 & 0.40 & 0.80 & 0.82 & 1.00 & 1.20 & 1.30 & 1.20 & $\underline{1.40^{1}}$ \\
\hline Lactobacillus sp. & 0.10 & 0.55 & 0.60 & 0.30 & 0.60 & 1.10 & 0.70 & 1.22 & 1.25 & $\underline{1.40}$ \\
\hline Leuconostoc sp. & 0.50 & 0.70 & 0.60 & 0.70 & 0.65 & 0.70 & 0.35 & 0.75 & 0.70 & $\underline{0.80}$ \\
\hline Corynebacterium sp. & 0.15 & 0.20 & 0.41 & 0.51 & 0.55 & 0.58 & 0.65 & 0.80 & 0.85 & $\underline{1.00}$ \\
\hline Bacillus sp. & 0.70 & 0.80 & 0.20 & 0.70 & 0.80 & 0.90 & 0.70 & 1.10 & 1.20 & $\underline{1.20}$ \\
\hline
\end{tabular}

${ }^{1}$ Figures in italics and underlined indicate the highest secretion for the treatment

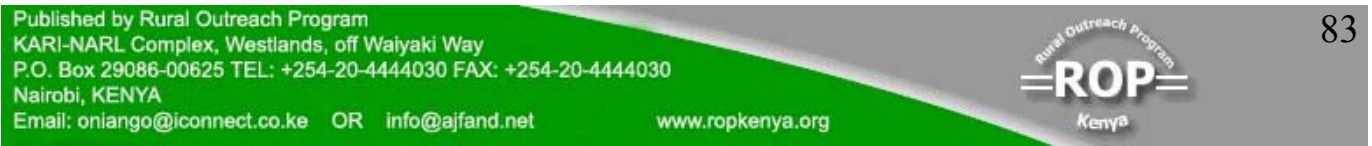




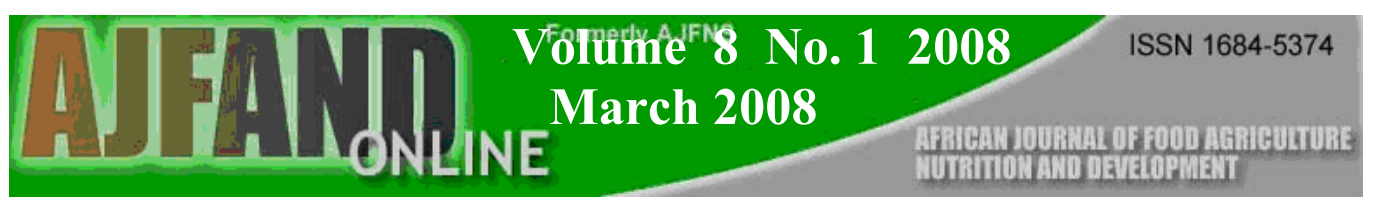

Table 2: Effect of nitrogen concentration on methionine secretion

\begin{tabular}{|c|c|c|c|c|c|c|c|c|c|c|}
\hline \multirow{3}{*}{ Organisms } & \multicolumn{10}{|c|}{ Methionine Secreted (g methionine/litre of medium) } \\
\hline & \multicolumn{2}{|c|}{$\begin{array}{l}5 \mathbf{g}\left(\mathrm{NH}_{4}\right)_{2} \mathrm{SO}_{4} \\
\text { /litre of medium }\end{array}$} & \multicolumn{2}{|c|}{$\begin{array}{l}\mathbf{1 0} \mathbf{g}\left(\mathrm{NH}_{4}\right)_{2} \mathrm{SO}_{4} \\
\text { /litre of medium }\end{array}$} & \multicolumn{2}{|c|}{$\begin{array}{l}\mathbf{2 0} \mathbf{g}\left(\mathrm{NH}_{4}\right)_{2} \mathrm{SO}_{4} \\
\text { /litre of medium }\end{array}$} & \multicolumn{2}{|c|}{$\begin{array}{l}\mathbf{3 0} \mathbf{g}\left(\mathrm{NH}_{4}\right)_{2} \mathrm{SO}_{4} \\
\text { /litre of medium }\end{array}$} & \multicolumn{2}{|c|}{$\begin{array}{l}40 \mathrm{~g}\left(\mathrm{NH}_{4}\right)_{2} \mathrm{SO}_{4} \\
\text { /litre of medium }\end{array}$} \\
\hline & $24 \mathrm{~h}$ & $48 \mathrm{~h}$ & $24 \mathrm{~h}$ & $48 \mathrm{~h}$ & $24 \mathrm{~h}$ & $48 \mathrm{~h}$ & $24 \mathrm{~h}$ & $48 \mathrm{~h}$ & $24 \mathrm{~h}$ & $48 \mathrm{~h}$ \\
\hline $\begin{array}{l}\text { Lactobacillus } \\
\text { plantarum }\end{array}$ & 0.15 & 0.22 & 0.30 & 0.50 & 0.30 & $\underline{1.20}^{1}$ & 0.42 & 0.50 & 0.38 & 0.40 \\
\hline Lactobacillus sp. & 0.30 & 0.82 & 0.30 & 0.85 & 0.45 & $\underline{1.20}$ & 0.30 & 0.40 & 0.15 & 0.20 \\
\hline Leuconostoc sp. & 0.22 & 0.28 & 0.50 & 0.65 & 0.30 & $\underline{0.70}$ & 0.30 & 0.50 & 0.20 & 0.25 \\
\hline Corynebacterium sp. & 0.30 & 0.40 & 0.50 & 0.70 & 0.60 & $\underline{0.90}$ & 0.05 & 0.10 & 0.05 & 0.05 \\
\hline Bacillus sp. & 0.70 & $\underline{0.80}$ & 0.35 & 0.60 & 0.28 & 0.65 & 0.35 & 0.40 & 0.25 & 0.40 \\
\hline
\end{tabular}

${ }^{1}$ Figures in italics and underlined indicate the highest secretion for the treatment

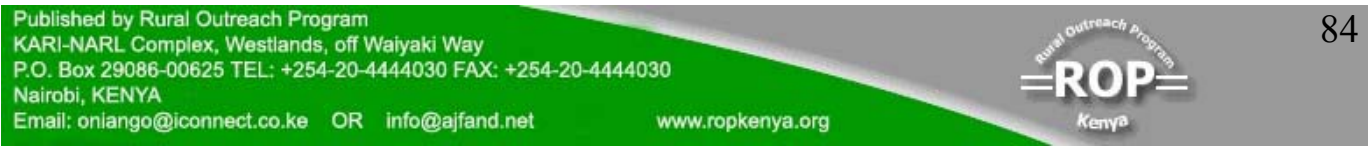




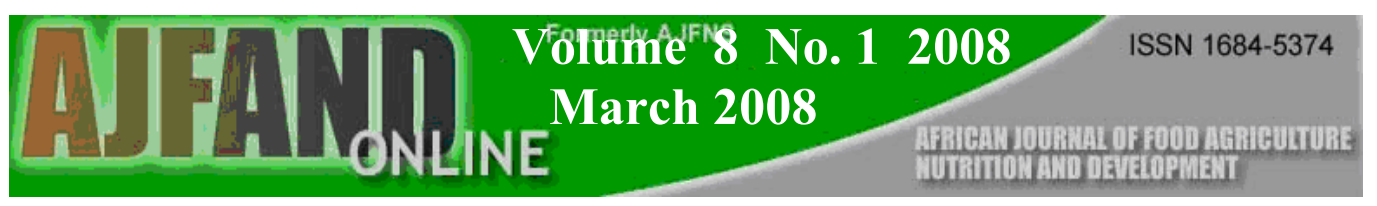

Table 3: Effect of phosphate concentrations on methionine secretion

\begin{tabular}{|c|c|c|c|c|c|c|c|c|c|c|}
\hline \multirow{3}{*}{ Organisms } & \multicolumn{10}{|c|}{ Methionine Secreted (g methionine/litre of medium) } \\
\hline & \multicolumn{2}{|c|}{$\mathbf{A}$} & \multicolumn{2}{|c|}{ B } & \multicolumn{2}{|c|}{$\mathbf{C}$} & \multicolumn{2}{|c|}{$\mathbf{D}$} & \multicolumn{2}{|c|}{$\mathbf{E}$} \\
\hline & $24 \mathrm{~h}$ & $48 \mathrm{~h}$ & $24 \mathrm{~h}$ & $48 \mathrm{~h}$ & $24 \mathrm{~h}$ & $48 \mathrm{~h}$ & $24 \mathrm{~h}$ & $48 \mathrm{~h}$ & $24 \mathrm{~h}$ & $48 \mathrm{~h}$ \\
\hline $\begin{array}{l}\text { Lactobacillus } \\
\text { plantarum }\end{array}$ & 0.60 & $\underline{\mathbf{1 . 6 0}}^{1}$ & 0.80 & 1.00 & 0.50 & 1.40 & 0.50 & 0.58 & 0.10 & 0.15 \\
\hline Lactobacillus sp. & 0.60 & $\underline{1.00}$ & 0.60 & 0.70 & 0.40 & 0.60 & 0.62 & 0.65 & 0.30 & 0.80 \\
\hline Leuconostoc sp. & 0.20 & 0.30 & 0.20 & 0.23 & 0.10 & $\underline{1.41}$ & 0.40 & 0.60 & 0.10 & 0.15 \\
\hline Corynebacterium sp. & 0.80 & 1.00 & 0.98 & $\underline{1.10}$ & 0.60 & 1.20 & 0.95 & 1.00 & 0.02 & 0.05 \\
\hline Bacillus sp. & 0.40 & 0.80 & 1.00 & 1.22 & 0.60 & $\underline{1.60}$ & 0.60 & 0.65 & 0.30 & 0.05 \\
\hline
\end{tabular}

${ }^{1}$ Figures in italics and underlined indicate the highest secretion for the treatment
$\mathrm{A}=0.5 \mathrm{KH}_{2} \mathrm{PO}_{4}, 1.5 \mathrm{~K}_{2} \mathrm{HPO}_{4}$
$\mathrm{B}=0.75 \mathrm{KH}_{2} \mathrm{PO}_{4}, 2.0 \mathrm{~K}_{2} \mathrm{HPO}_{4}$
$\mathrm{C}=1.0 \mathrm{KH}_{2} \mathrm{PO}_{4}, 3.0 \mathrm{~K}_{2} \mathrm{HPO}_{4}$
$\mathrm{D}=1.5 \mathrm{KH}_{2} \mathrm{PO}_{4}, 4.0 \mathrm{~K}_{2} \mathrm{HPO}_{4}$
$\mathrm{E}=2.0 \mathrm{KH}_{2} \mathrm{PO}_{4}, 6.0 \mathrm{~K}_{2} \mathrm{HPO}_{4}$

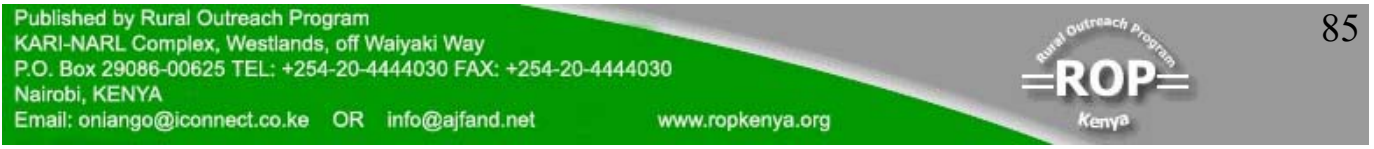




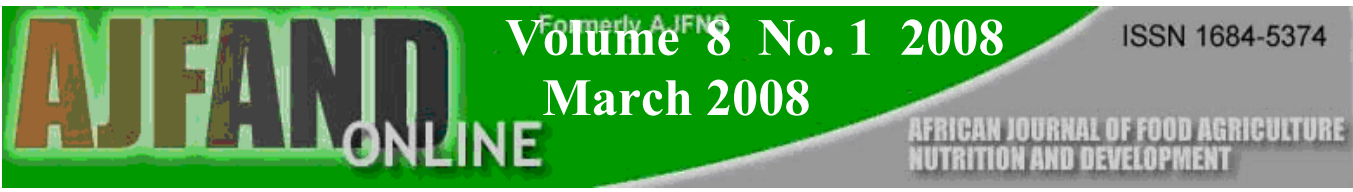

Table 4: Composition of the medium Giving Optimal Methionine secretion for each Organism

\begin{tabular}{|c|c|c|c|}
\hline Organism & Glucose (g) & Nitrogen & Phosphate \\
\hline $\begin{array}{l}\text { Lactobacillus } \\
\text { plantarum }\end{array}$ & 10 & $20 \mathrm{~g}\left(\mathrm{NH}_{4}\right)_{2} \mathrm{SO}_{4} /$ litre & A \\
\hline Lactobacillus sp. & 10 & $20 \mathrm{~g}\left(\mathrm{NH}_{4}\right)_{2} \mathrm{SO}_{4} /$ litre & A \\
\hline Leuconostoc sp. & 10 & $20 \mathrm{~g}\left(\mathrm{NH}_{4}\right)_{2} \mathrm{SO}_{4} /$ litre & $\mathrm{C}$ \\
\hline Corynebacterium sp. & 10 & $20 \mathbf{g}\left(\mathrm{NH}_{4}\right)_{2} \mathrm{SO}_{4} /$ litre & B \\
\hline Bacillus sp. & 10 & $5 \mathbf{g}\left(\mathrm{NH}_{4}\right)_{2} \mathrm{SO}_{4} /$ litre & $\mathrm{C}$ \\
\hline
\end{tabular}
$\mathrm{A}=0.5 \mathrm{KH}_{2} \mathrm{PO}_{4}, 1.5 \mathrm{~K}_{2} \mathrm{HPO}_{4}$
$\mathrm{B}=0.75 \mathrm{KH}_{2} \mathrm{PO}_{4}, 2.0 \mathrm{~K}_{2} \mathrm{HPO}_{4}$
$\mathrm{C}=1.0 \mathrm{KH}_{2} \mathrm{PO}_{4}, 3.0 \mathrm{~K}_{2} \mathrm{HPO}_{4}$
$\mathrm{D}=1.5 \mathrm{KH}_{2} \mathrm{PO}_{4}, 4.0 \mathrm{~K}_{2} \mathrm{HPO}_{4}$
$\mathrm{E}=2.0 \mathrm{KH}_{2} \mathrm{PO}_{4}, 6.0 \mathrm{~K}_{2} \mathrm{HPO}_{4}$

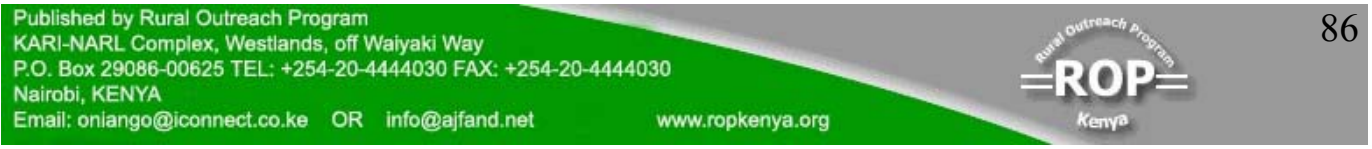




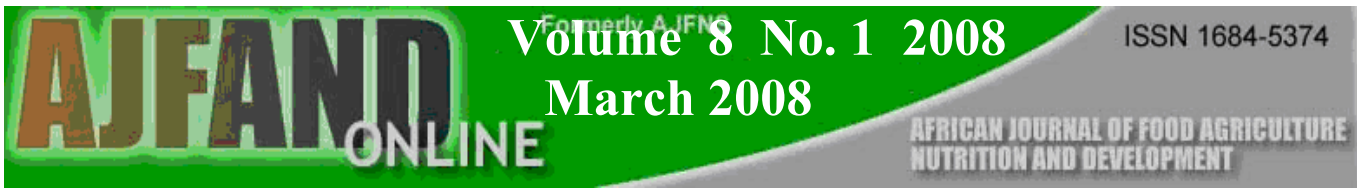

Table 5: Effect of Length of Incubation Time on Methionine Secretion

\begin{tabular}{|l|l|l|l|l|l|l|}
\hline \multirow{2}{*}{ Organisms } & \multicolumn{5}{|c|}{$\begin{array}{c}\text { Methionine secreted by the various organisms } \\
\text { (g methionine/litre of medium) }\end{array}$} \\
\cline { 2 - 7 } & $24 \mathrm{~h}$ & $48 \mathrm{~h}$ & $72 \mathrm{~h}$ & $96 \mathrm{~h}$ & $120 \mathrm{~h}$ & $144 \mathrm{~h}$ \\
\hline $\begin{array}{l}\text { Lactobacillus } \\
\text { plantarum }\end{array}$ & 1.60 & 2.04 & 3.00 & $\underline{\mathbf{3 . 4 8 ^ { 1 }}}$ & 3.45 & 3.10 \\
\hline $\begin{array}{l}\text { Lactobacillus sp. } \\
\text { Leuconostoc sp. }\end{array}$ & 1.45 & 1.90 & 2.89 & $\underline{\mathbf{3 . 3 0}}$ & 3.22 & 2.98 \\
\hline $\begin{array}{l}\text { Corynebacterium } \mathrm{sp} . \\
\text { Bacillus } \mathrm{sp} .\end{array}$ & 1.5 & $\underline{\mathbf{2 . 4 8}}$ & 2.45 & 2.30 & 2.20 & 2.07 \\
\hline
\end{tabular}

${ }^{1}$ Figures in italics and underlined indicate the highest secretion for the treatment 
Table 6: Quantity of Methionine Secreted by Each Organism when offered Optimum medium Components and Optimum Incubation Time

\begin{tabular}{|c|c|c|c|c|c|c|}
\hline \multirow[t]{2}{*}{ Organisms } & \multicolumn{4}{|c|}{ Medium Contents for Optimum Methionine Secretion ${ }^{1}$} & \multirow{2}{*}{$\begin{array}{l}\text { Optimum } \\
\text { Incubation } \\
\text { Time (hr) }\end{array}$} & \multirow{2}{*}{$\begin{array}{l}\text { Methionine } \\
\text { Secreted } \\
\mathrm{g} / \mathrm{L}\end{array}$} \\
\hline & Glucose & $\begin{array}{l}\left(\mathrm{NH}_{4}\right)_{2} \mathrm{SO}_{4} \\
\mathrm{~g} / \mathrm{L}\end{array}$ & $\mathrm{KH}_{2} \mathrm{PO}_{4}$ & $\mathrm{~K}_{2} \mathrm{HPO}_{4}$ & & \\
\hline $\begin{array}{l}\text { Lactobacillus } \\
\text { plantarum }\end{array}$ & 10 & 20 & 0.5 & 1.5 & 96 & 3.48 \\
\hline Lactobacillus sp. & 10 & 20 & 0.5 & 1.5 & 96 & 3.30 \\
\hline Leuconostoc sp. & 10 & 20 & 1.0 & 3.0 & 72 & 2.76 \\
\hline $\begin{array}{l}\text { Corynebacterium } \\
\text { sp. }\end{array}$ & 10 & 20 & 0.75 & 2.0 & 48 & 2.48 \\
\hline Bacillus sp. & 10 & 5 & 1.0 & 3.0 & 72 & 1.35 \\
\hline
\end{tabular}

${ }^{1}$ Medium components were added to a basal medium with: $0.5 \mathrm{~g}$ of glucose and $5 \mathrm{~g}$ of yeast extract per litre 


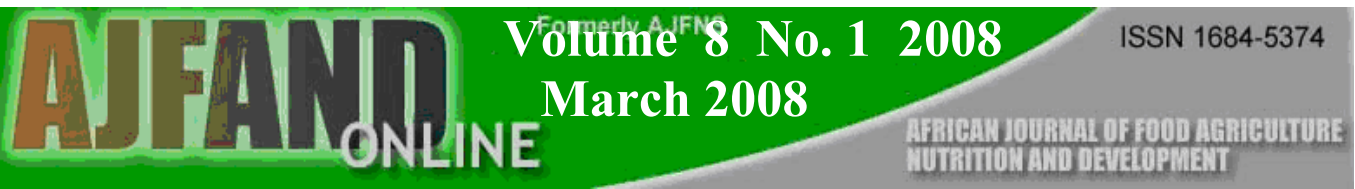

\section{REFERENCES}

1 Okafor N, Umeh C, Ibenegbu C, Obizoba I and $M$ Nnam Improvement of garri quality by the inoculation of microorganisms into cassava mash. Int. $J$ Fd Microbiol 1998a; 40: 43 - 49.

2 Okafor $\mathbf{N}$, Umeh $\mathbf{C}$ and $\mathbf{C}$ Ibenegbu Amelioration of garri, a cassava based fermented food by the inoculation of microorganisms secreting Lysine. Int. $J$ Fd Microbiol 1998b; 40: 48 - 51 .

3 Oyewole $\mathbf{O B}$ Characteristics and significance of yeasts' involvement in cassava fermentation for 'fufu' production Int. J Fd Microbiol, 2001; 65: 213218.

4 Borton B Human Nutrition. New York: McGraw-Hill. 1978.

5 Gelenberg AJ Tyrosine for the Treatment of Depression. Am. J Psych 1980; 137: $622-3$.

6 Kelly TL, Neaga OR, Schwahn BC, Rozen R and JM Trasler Infertility in 5,10-Methylenetetrahydrofolate Reductase (MTHFR)-Deficient Male Mice is Partially Alleviated by Lifetime Dietary Betaine Supplementation Bio. Reprod 2005; 72: 667-677.

7 Chay BP, Flor CF, Galvez T and GP William Methionine Production by batch fermentation from various carbohydrates. ASEAN Fd $J$ 1992; 7: 34 37.

8 Gomes J and D Kumar Production of L-Methionine by Submerged Fermentation: A review, Enz. Microbial Technol., In press: accepted Jan 2005.

9 Okafor $\mathbf{N}$ Micro-organisms associated with dead insect larvae in Nigeria, Nature, 1965; 208: 1015-1016.

10 Holt JG, Krieg NR, Sneath PHA Staley, JT and ST Williams Bergey's Manual of Determinative Bacteriology. Williams and Wilkins, Baltimore, Maryland 1994.

11 Rosen HA modified ninhydrin colorimetric analysis for amino acids. Arch Biochem and Biophys 1957; 67:10-15.

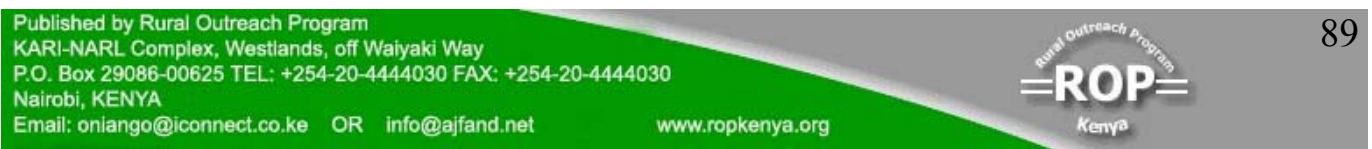




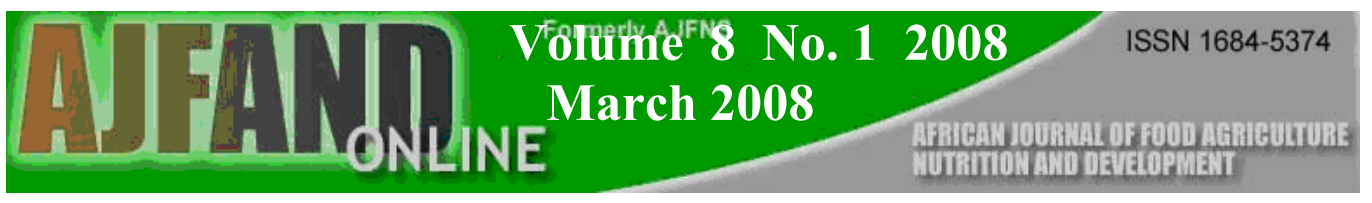

12 Odunfa S and EY Adewuyi Optimization of process condition for the fermentation of African Locust bean (Parkia biglobosa), Effect of time, temperature and humidity. Chem Microbiol Techn Leben. 1985; 1 9: 6-10.

13 Abe MD and RC Lindsay Evidence for a streptococcal role in Nigerian acidic cassava (Manihot esculenta Crantz) fermentations. J. Fd Prot. 1978; 41: $781-783$.

14 Amoa- Awua WKA, Appoh F and M Jakobsen Lactic Acid Fermentation of cassava into agbelima. Int. J Fd Microbiol 1996; 31: 87 - 98.

15 Collar P and S Levi A two-stage fermentation of cassava. Nature, 1959; 183: 620-621.

16 Okafor N Microorganisms Associated with Cassava Fermentation for Garri Production. J Appl.Bact 1977; 42: 279 - 284.

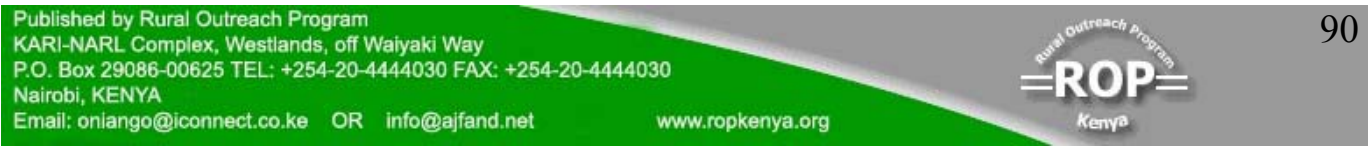

